\title{
A Study of Risk Control of the Mode of "Internet Finance +PPP" Zhenjie Xie ${ }^{1, a}$ and Xin'e Zhao, b \\ 'School of Management, Wuhan University of Technology, Wuhan, 430070, China a2399609070@qq.com, bxehb2001@163.com
}

Keywords: Internet finance; PPP; Risk control, Infrastructure construction

\begin{abstract}
As a new financial model, "Internet Finance +PPP" is popular because of its low cost, high efficiency characteristics. PPP model works on introducing social capital into the infrastructure investment .The combination of the two models will form a new pattern of economic cooperation. And "Internet Finance +PPP" model will become an important financial means of infrastructure projects. However, since this new pattern is still on the exploration stage, there will be a variety of risks in their practical application. This paper mainly analyzes the main risks of this model, and proposes the corresponding control measures.
\end{abstract}

\section{Introduction}

With development of Chinese economic entering the "new normal economy", the growth rate of fiscal revenue dropped significantly, the need of infrastructure funding of local government constantly increases too. Therefore, it is imperative to introduce the model of PPP, namely public-private partnerships. PPP is a kind of project financing mode in public infrastructure construction, which can give full play to the advantages of local government and private enterprises, improve the efficiency and quality of public service supply, and achieve long-term incentive compatibility [1]. PPP is designed to control and transform government debt, to encourage private enterprises to participate in infrastructure construction. But how to guide private enterprises to participate in the public products and public services and obtain a reasonable return, while reduce the investment of local government pressure and make more funds for the construction of high-quality public products? Under this circumstance, a new financing model Internet Finance +PPP model came into being.

\section{Methods}

Characteristics of Internet Finance +PPP model. "Internet finance +PPP" is an Innovative financing model that the local government and the private enterprises contract based on partnership, through benefit sharing, risk sharing mechanism, Internet banking as a financing channel to attract private capital to participate in infrastructure construction. This model can solve the problem of shortage of funds of government investment effectively, and can provide idle private capital with investment channels which share a long-term and stable investment income brought by government infrastructure, can revitalize the public and social investment and financing projects and funds. It can improve investment efficiency and profit of the project financing, promote infrastructure construction.

First, it can play the advantages of the Internet banking in the financial market. Using the advantages of the data collection and analysis ability of cloud computing and big data, the Internet financial platform provides private enterprises (the demand side) and Internet investors (fund provider) with the market [2]. It can effectively alleviate the problem of asymmetric information on Internet investors and PPP, improve financing efficiency, and effectively reduce the capital needed for PPP model in cost and financial risk.

Second, this model can promote the transformation of local government functions, private enterprises, as well as the healthy development of Internet finance. Private financial companies use the Internet finance to raise the necessary funds for infrastructure construction to solve the problems of local government infrastructure construction fund shortage, speeding up the local government in 
the infrastructure construction and making more people benefit. At the same time, the cooperation between local government and private enterprises can make up for the deficiencies in the management of local governments and introduce the advanced management experience and technology. The local government can reduce the energy input in the micro business, and have more time and energy to increase the intensity of macroeconomic regulation and control, so that achieve the transformation of government functions [3].

Third, the government, private enterprises and Internet investors share interests and risk. The government, private enterprises and Internet investors achieve their goals through cooperation, the government provides public services, private enterprises and Internet investors realize returns while providing service. Government and private enterprises as well as Internet investors bear different risks with their own advantages. The management who can deal with the risk efficient can be allocated the specific risk to achieve complementary advantages [4]. For example, government departments can make corresponding policies to exert influence on the project, but lack of funds and management experience; Internet investor have capital adequacy, but lack of investment channels; private enterprises have a wealth of management experience and innovative ability, but the risk tolerance capacity is limited. PPP company can contract the project construction to a construction enterprise with rich experience in construction, also can transfer the operator to the firms which have advanced management technology, it can reduce the risk in project construction and operation.

Internet financial +PPP mode operation mode can be summarized as shown in figure 1 .

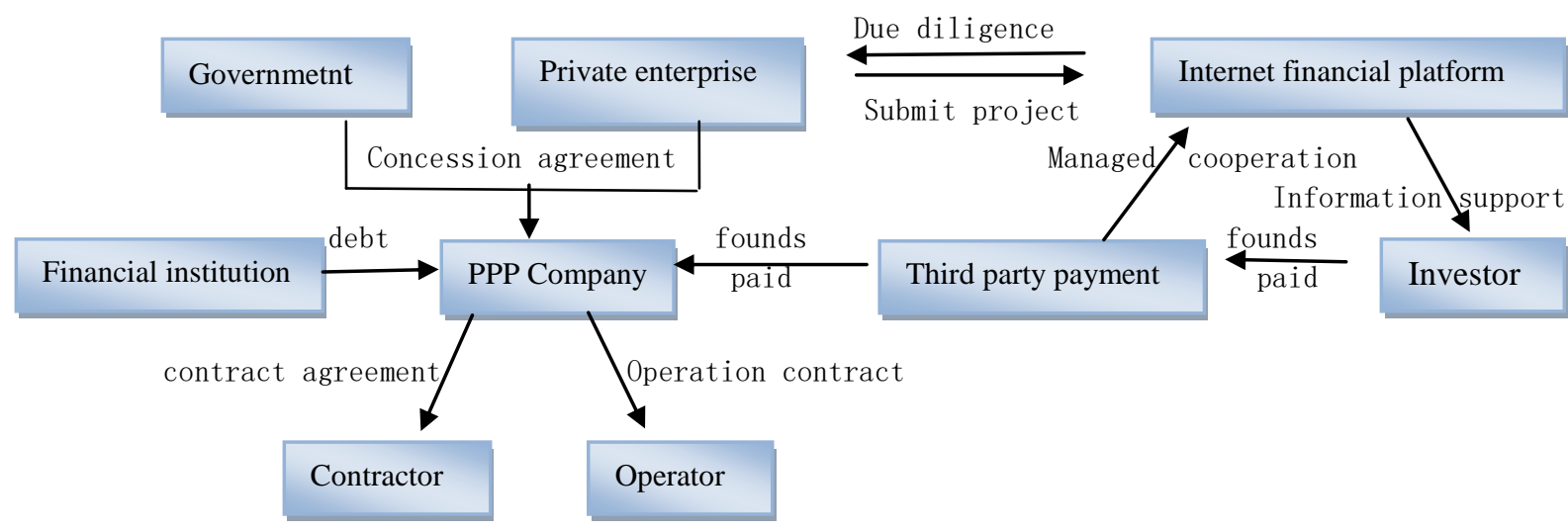

Figure 1 Internet finance + PPP mode operation mode

The Operation Stage of Internet Finance +PPP. PPP project identification and preparation stage. The local government is responsible for this stage mainly. Government sector finish the project initiation, screening, evaluation of the value of money, the preparation of the project implementation plan and establish the implementation of institutions, then it issues a tender notice, organizes private enterprises into bidding activity and signs a contract with the bid winning enterprise.

Financing stage. Private enterprises and Internet financing platform take the advantages of the Internet to finance to publish project financing information to complete the financing objectives in the specified time.

Construction stage. Private enterprises and local governments set up Item Company that is responsible for the management of the entire project. PPP Item Company signs the construction contract with a strong management ability of the contractor, then the contractor finish the project construction. During the construction process, PPP Item Company discloses the progress of the project in the Internet finance platform timely.

Transition stage. PPP Item Company chooses operators which has operations and maintenance experienced and higher level of management when the item finished. It pays the investment returns to the investors according to the operating income.

Internet finance +PPP model is the combination of Internet financing and PPP of economic cooperation mode, link the private capital and the government infrastructure projects to improve efficiency and reduce the cost of financing. But the Internet finance +PPP will be faced with many 
problems in the practical application process. This paper analyzes the main risks of this innovative model from the law, government credit, public recognition, private enterprise operation ability.

Legal risk. Clear and definite laws and regulations are the guarantee for the private capital to enter into and out of the facilities and the public service supply. Internet finance + PPP require not only a large amount of capital investment but also a longer period of time. Private capital will take into account the risk when it enters such a project. Imperfect laws and regulations will increase the risk of Internet finance $+\mathrm{PPP}$ during the operation. Internet finance $+\mathrm{PPP}$ model is a new financing model that combine Internet finance and PPP model. Existing laws and regulations can't assign the rights, obligations and risk to each participant effectively, which cause the Internet investors and private enterprises to lose economic benefits. Internet finance +PPP model is a cross-market, cross-domain, cross-business cooperation. Lacking appropriate legal policy, the model will be a lack of legal supervision during the operation and will break the law easily in the course of business development, which is not conducive to the development of the Internet finance +PPP. From the current financial legal and PPP legal policy and the legal system often appear after the problem, it can't prevent the occurrence of legal risk effectively. Facing the Internet finance problems, regulators adopted a one size fits all policies, the regulatory authorities take a "blanket" policy and issue regulations that limit the amount of Internet finance [5].

Government Credit Risk. Government credit risk refers to the government does not perform the agreement in the process of Internet finance +PPP model so that bring harm to private enterprises and Internet investors, as well as infrastructure projects. Private enterprises get the recognition from the Internet investors with the government credit endorsement infrastructure when they use Internet finance platform for financing. But some local government does not have strong market contract spirit. To solve the financial pressure, the government takes Internet finance $+\mathrm{PPP}$ as a temporary financing model. In order to speed up the local infrastructure construction, sometimes some government sign from the impracticable agreement with the private enterprises to attract private capital. The government can't fulfill obligations in accordance with the contract when the project finished. The government regardless the post operation the project and not considering the constancy of the entire project will bring directly damage to the interests of private enterprises and Internet investors, and negative effects to the government credit [6]. The Internet finance + PPP mode emphasizes the cooperation between the government and private enterprises during project cycle. Both sides are equal to share risk and benefit. The government is in the dominant position, while the private enterprise is in the weak position in the actual operation process. Whether the government can practice the spirit of market contract relationship decides the success or failure of the whole model. Government departments' not performing the agreement, will dampen the enthusiasm of private capital investment and result in large losses to private capital, will cause more difficult to the project to continue for lacking of trust and cooperation.

Public Recognition Risk. Although PPP has become a national strategy and the government also pays great attention to it, the degree of social capital is relatively low, especially private capital make up very low proportion in the PPP model. Integration of Internet finance and PPP model will attract more private capital to participate, but the public's recognition of the Internet finance +PPP model has yet to be discussed. The main reasons are :(1)although the Internet finance platform do due diligence to private enterprises financing to reduce information asymmetry and let the public get more project information, it still can't reduce the risk of Internet investors effectively. This is because the PPP project launched by the government is not high profit and low risk project that is expected by investors. The construction period of PPP project is longer, which will take a long time to achieve profitability. In addition, the PPP project is the construction project which belongs to the public welfare projects. The government will limit the return on investment during operation, and therefore it can't produce significant benefits, so as to reduce the attractiveness of investors. (2) The Internet finance + PPP mode is lack of incentive mechanism for long-term stability. The infrastructure of the PPP project has the characteristics of low yield and long cycle, which makes lower the enthusiasm of the internet investors Therefore, the government needs to take financial subsidies, tax incentives and 
other incentives, but the current measures introduced by the authorities are far from meeting the needs.

Private Enterprises Operating Risk. The private enterprises operating capacity risk is mainly reflected in the following two aspects: (1) PPP project operation management ability risk. The private enterprise is not only involved in the construction of the entire infrastructure, but also involved in the project post operation in the Internet finance +PPP model. In the period of project construction, the risk of each phase is a challenge to the private enterprise from the choice of the project to the completion of the project. During this period, the private enterprise must have the ability to get the assistance committed by government timely, so as not to face the risk of financial chain rupture. If lacking the advanced management experience or not developing an effective pricing mechanism, private enterprises will extend the payback period and increase the cost of capital during the operation.(2)The financing capacity of private enterprises in the financial market risk. The private enterprise attracts investment from the Internet investors through the Internet finance platform spreading information on PPP project. A feature of the Internet finance +PPP mode is that the government and the successful bidder sign the concession agreement which comes into effect when the successful tender finishes financing within the specified period of time, or it will be disqualified.[7]

\section{Summary}

Improve PPP and Internet Finance Legal System. In view of the legal risks, the government should speed up the legislative process to improve the PPP and Internet finance laws and regulations and to provide legal protection for the operation of Internet finance +PPP. First, it is better to clear the boundaries of the Internet finance business, to establish the regulatory responsibilities of Internet finance and to develop laws that conform to the laws of market development as soon as possible. Meanwhile, it should strengthen industry self-discipline on Internet finance to make up the lag of the development of national laws, to improve the prevention of financial risks to the Internet finance. Second, government can set different information disclosure standards for different amount of funds in the formulation of the law. It can fully lower the limit of funds for the large scale financial needs of Internet finance +PPP which need private enterprises and the government to provide detailed information disclosure to avoid the risk of financial failure. Third, in the process of making the law, government should fully considerer considers the impact on the existing Internet finance +PPP and introduces appropriate guidance to guide the amendment of the irregular contract. It should establish an evaluation model that includes PPP project financing, construction and operation as well as the use of funds for supervision on the mechanism corresponding to Internet finance $+\mathrm{PPP}$, then disclosure in PPP Internet finance information platform do that protect the interests of the participants. Fourth, the relevant laws should be up to the national level to clear the rights and obligations of the government and social capital, the explicit contract framework, government regulation, social capital and launch mechanism to improve the legal constraints on the Internet, private enterprises and government investors [8].

Improve the modern Management and Governance Capacity of local Government. In the face of the question of public credibility, the local government should strive to improve its image and to improve the ability of modern management and governance. First, the local government should make laws and regulations support the operation of Internet finance + PPP, It should be an actively player not a referee, and create a good investment environment so that more private capital participate in infrastructure construction. Second, government departments should strengthen the spirit of contract. It is better to establish contract system to make clear provisions on the responsibilities of government departments, determine the basis for the government's breach of contract and make different degrees of punishment to punish relevant government departments and responsible person [9]. Finally, the local government should strengthen the study of PPP and Internet finance. Screening of PPP projects, the determination of the yield of the project, the government subsidies and Internet financing methods need a lot of professional knowledge and professional talent. 
Improve the Attractiveness of PPP Projects. Whether to attract private capital participation is the key to the success of the application of Internet finance +PPP model. Private capital aims to pursue investment returns, because reasonable investment returns will increase the participation enthusiasm of private capital. At the same time the government should direct or indirect compensate PPP item for the use of the form of monetary and non monetary for most of the PPP project is a non-profit, quasi business projects, namely tax exemptions, subsidies, the purchase of services, extending the concession period and a variety of modes, it effectively reduce the operating costs of the item company and increase income in disposable. Government supervises the SPV to improve the governance structure and formulate reasonable dividend distribution system to protect Internet investors' benefit [10]. Government can compensate PPP item for the project resources to achieve the expected benefits of the project to promote the implementation of the project to meet the legitimate channels of PPP Item Company to obtain the expected benefits. For example, government can provide the appropriate resources for the development of the project development, supporting services and by-products, namely, the supply of visible public resources in the mode of binding or joint supply.

Strengthen Cooperation among Enterprises. In the "Internet Finance + PPP" mode, private enterprises should be responsible for project design, construction, financial management, and operation and maintenance. What's more, they are also in charge of the project financing, information disclosure and other tasks while communicating with the local government [11]. That is undoubtedly a huge challenge for private enterprises. Concerning that the construction of infrastructure projects always tend to have high standards, private enterprises should pay attention to skills and experience of the construction and management in the process of selecting contractors. Operators need to have rich professional experience to ensure the safety and stability of the project for a long period of operation of the PPP project. In addition, private enterprises should strengthen cooperation with financial enterprises. Relying on the advantages of the capital market, financial enterprises can introduce the PPP project to the financial market to attract more Internet investors and to reduce the cost of financing.

\section{References}

[1] C.Y. W, X.Y. Zhang, Y. Cheng, Difficulties and Countermeasures in the implementation of PPP -- Based on the investigation of Anhui, Fiscal Science, 2016, 01:103-108.

[2] Y.X. Mo, Competition and Cooperation between Traditional Finance and Internet Banking, Finance and Accounting Monthly.2014, 14:50-53

[3] Q.J. Z, Promotion and application of Internet enterprises in PPP model, Anhui Science \& Technology, 2015, 02:26-27

[4] K. J,J. Sun, The concept, origin, characteristics and functions of public private partnership (PPP), Fiscal Studie, 2009, 10:2-10

[5] W.B. F, Research on Internet financial +PPP model, Financial Theory and Practice, 2015, $12: 52-55$

[6] Y.X. L, Practice reflection and policy suggestion of PPP model, Economist, 2016, 04:78-80

[7] X. Q, Y.J. Ke, Analysis on the mainRisk Factors of PPP Project in China based on Case, Chinese Soft Science. 2009, 05:107-113

[8] W L, Interpretation of PPP model theory and its practical illustration, Reform, 2015 ( 1) : 78-89

[9] Z.X Z,X.Q Zhang, Problems and solutions in the application of PPP mode under the new normal state, Chinese Soft Science, 2015， 09:82-95 
[10]J M, Research on Internet banking +PPP model based on the construction of infrastructure, Journal of Zhongzhou University, 2016， 02:10-15

[11]T.J J,L.Y Wang, Restriction factors and Countermeasures of small and medium sized enterprises' participation in PPP in China, Operating Management,2016(4)73-76 